\title{
The Intricacies of Female Successors in Family Owned Businesses
}

\author{
Nnabuife Ezimma K. (Correspondence Author) \\ Department of Business Administration, Nnamdi Azikiwe University \\ Awka, Anambra State, Nigeria \\ E-mail: ezimmannabuife@gmail.com
}

Okoli Ifeanyi Emmanuel

Department of Entrepreneurial Studies, Nnamdi Azikiwe University

Anambra State, Nigeria

E-mail: eokoli76@yahoo.com

\begin{abstract}
Arachie Augustine Ebuka
Department of Business Administration, Nnamdi Azikiwe University

Awka, Anambra State, Nigeria

E-mail: arachieaustine@gmail.com
\end{abstract}

\author{
Adani Nnenne Ifechi \\ Department of Entrepreneurial Studies, Nnamdi Azikiwe University \\ Anambra State, Nigeria \\ E-mail:nnenneluv@yahoo.com
}

Received: April 17, 2019

Accepted: May 18, 2019

Published: June 24, 2019

doi:10.5296/jebi.v6i1.14680

URL: http://dx.doi.org/10.5296/jebi.v6i1.14680

\section{Abstract}

As a result of shortage of female successor due in part to gender bias succession practices, 
this study was necessitated to look at encumbrances against women successors of Family Owned Businesses (FOBs) in Anambra State. The broad objective of this study was to examine female successors and sustainability of family owned businesses. The work adopted a survey research design. The population of the study was 415 FOBs in Anambra State. Complete enumeration method was adopted so as to get the full opinion of all firms on gender issues and female succession. The data for the study was collected through structured questionnaire. A combination of descriptive (mean) and inferential statistics (chi-square) were deployed in the data analysis. The result showed that there are obstacles that have substantial effect on women becoming successors of FOBs in Anambra State and that sexism play a statistically significant role in determining successors in Anambra State. Sequel to this, it was concluded that women and men in Anambra State do not have a level playing ground in determining who becomes a successors of FOBs in Anambra state as there are hurdles women face and these obstacles have significant effect on who becomes a successors. Hence, the recommendation was that successors of FOBs should not be based on gender but on capability and the provision of level playing ground for both the female and male genders in the succession dynamics.

Keywords: Family Owned Business, Female Successor, Succession, Sexism and Sustainability

\section{Introduction}

Family Owned Businesses (FOBs) are not new in the business lexicon and some people have posited that it is the oldest and most popular form of business even as at today. It dominates other forms of businesses in America, Europe and even in Nigeria and Anambra State which is the focus of this study. Corroborating this position, Efferin and Hartono (2015) and Martí, Menéndez-Requejo and Rottke (2013) opine that FOBs are the prevailing forms of organisations worldwide, being the determinants of the social and economic development of both developed and emerging economies. Most firms around the world are controlled by families, founders or their heirs (Faccio \& Lang, 2002). Approximately 64\% of U.S. gross domestic product is generated by family businesses (Astrachan \& Shanker, 2003). Similarly, Oyeyinka (2010) posits that approximately $96 \%$ of Nigerian businesses are private indigenous enterprises which are mainly FOBs and this situation is not different in Anambra State.

Just as there are many businesses that qualify as FOBs, so also are there studies on FOBs and their succession. However, most of the studies appear to be gender blind, which skews the studies towards father-son kind of transfer of mantle of leadership. Giving credence to this assertion, Sonfield and Lussier (2009) state that there has been a growing concern about the significant gender imbalances in entrepreneurial activity. They further opine that despite a growing interest on gender in new venture activity, gender is largely unexplored in family firms. Research about the role and involvement of women in family businesses is limited by fragmentation and a lack of empirically based study (Martinez Jimenez, 2009). This research gap is further evidenced in that much of the research on parent-child relationships in the context of generational transfer of family business has focused on the father-son dyad, with 
little attention paid to gender differences in family business succession (Habberman \& Danes, 2007). This could be attributed to a lot of things, culture being the main part of the reason as male children are perceived to be more competent and destined to succeed in business than female children.

Culture and background seem to have skewed the mind-set such that whenever a successor to a business is thought about, a man or a male child always comes to mind. Fritsch (2017) avers that why literature actually focuses specifically on the successor; daughters are usually seen as less suitable successors than men. Indeed, strongly embedded societal stereotypes and prejudices nowadays have resulted in a situation whereby; in general, male successors are more often seen as capable of being the head of the family business (Fritsch, 2017). A literature on parental gender preferences in the U.S. highlights that fathers, in particular, still favour sons over daughters (Dahl \& Moretti, 2008).

A host of reasons have been attributed to the limited number of women taking over FOBs from their fathers, mothers or other family members as the case may be. Sexism and stereotype are among the reasons. Also pinpointed are lack of trust on the business competencies and capabilities of women and viewing women only on their traditional role of housekeeping and child upbringing. Faraudello \& Songini (2018) opine that gender stereotypes and sexism are still quite strong when we look at the possibility of women occupying top management positions. Nowadays, still many obstacles, stereotypes and mistrust are preventing women from reaching important positions. Martin (2001) in a study of UK family businesses found that daughters had less access to training, qualifications, and networking opportunities than sons and that sons were viewed as the "designated heirs" to the business. These issues appear to be hindering female succession in FOBs and it is at the backdrop of these that this study was necessitated.

\subsection{Statement of the Problem}

Family Owned Businesses (FOBs) are no doubt part of the bedrock of many economies of the world. They help in providing jobs, paying taxes and thereby contribute to the economic growth of most nations. However, many of these businesses do not survive beyond the first generation, a situation which has been attributed to succession issues in the businesses. Most of the studies on succession and its planning and implementation over the years appear to be gender blind, thereby making the studies to be skewed to male succession. The fathers view their sons to be better positioned to take over the business; this is also given some cultural backing especially in Africa where Nigeria and Anambra State are situated. Women appear to be relegated to play only support roles if any as women are traditionally viewed as family caretakers; they cook, wash and take care of the home while the men go out to hustle and make money. They are therefore denied the opportunity to be groomed at an early stage so as to prepare them for a business life. Thus, there are very few women successors in FOBs in Anambra State. Therefore, this study is deemed necessary to examine the obstacles hindering women or daughters from being able to take over from their fathers, mothers or other family members as the case may be.

\subsection{Objectives of the Study}


The objectives of this study are:

a) To identify the major obstacles to women succeeding their parents in FOB's in Anambra State.

b) To examine the role sexism play in determining a successor to FOBs in Anambra State

\subsection{Hypotheses}

a) There are no obstacles to women succeeding their parents in FOB's in Anambra State.

b) Sexism does not play any role in determining a successor to FOBs in Anambra State

\section{Review of Related Literature}

\subsection{Family Owned Business}

Family Owned Businesses (FOBs) have garnered a lot of interest as a result of the leading roles they play in many economies of the world. FOBs have their place in history as they have existed for a very long time hence they are regarded as the oldest form of business (Nnabuife \& Okoli, 2017). Constantinidis \& Nelson (2009) explicate that FOB is of particular interest for research as it represents a dominant form of business structure and contributes substantially to economic development worldwide. Statistics show that more than $95 \%$ of U.S. businesses are family controlled, contributing to $40 \%-45 \%$ of the Gross National Product and in the EU, family businesses represent more than half of all registered firms (Price Water House Coopers, Family Business Survey 2007-2008). A study by the Economic Intelligence Unit (2013) in Nigeria suggests that $51.5 \%$ of the 200 largest listed companies are family-controlled businesses.

Family Owned Business just like the name implies has to do with business ventures owned by a family or combination of families. It could also be businesses where family members own greater stake in form of management and control or shares as in corporations. Schramy (2010) opine that FOB is seen as a group of people who are either connected due to their family relationship or due to their marriages, enabling them to thus become a part of the family. Thus, for a business to qualify as an FOB, family(s) must have significant influence in it. It could be in form of management or shares. This was corroborated by Prym (2011) who opines that "as it happens, scholars do agree on the fact that the term family business does describe itself in the sense that the family plays a significant and leading role in the business".

Cullen (2007) defines FOB as one which has been started by an entrepreneur/founder and eventually progresses to being owner managed and then results in more than one member working in the business, which leads to a family partnership. It is a business that is owned and directly influenced by members of the same family, who share the intention of creating wealth for future generations (Maas \& Diederichs, 2007). What is central in all the definitions of $\mathrm{FOB}$ is that it requires one form of family participation or the other. 


\subsection{Succession in FOBs and Female Successors}

Many FOBs fail to sustain the business especially after the demise of the owner/founder, an issue which has been attributed to lack of succession plan. Only one third of family businesses worldwide successfully manage the transition from one generation to the next (Constantinidis \& Nelson, 2009). Majority of the businesses are either sold or dismantled after the founder's death, for different reasons including lack of business viability, failure to engage succession planning, the founder's resistance to "let go" and/or the offspring's reluctance to join the firm (Price Water House Coopers, Family Business Survey 2007-2008).

Succession planning has grown in importance and significance over the years as a result of the great role it plays in ensuring that organizations transit seamlessly from one leadership/management or ownership to another (Nnabuife \& Okoli, 2017). Succession literally means to come after something, to take over from something or somebody. Relating to FOBs, it is the transition of ownership and control of business from one family member to another. Succession according to the German Duden, is described as "the takeover of a certain position, function, place or rank by a predecessor; successorship" (Bibliographisches Institute, 2017). It is the simultaneously passing of the managerial baton, the torch of family leadership and the ownership control to another member of the family (Poza, 2004).

Succession is not a one off event; it is systematic and procedural. It takes time and series of steps. It is a series of actions, events and developments that affect the transferral of managerial control from one family member to another (Sharma, Chrisman, Pablo \& Chua, 2001). It is a process that takes place over a number of years (Henry, Erwee \& Kong, 2013). Researching the family firm from a resource and knowledge basis leads to viewing the succession process as a longer-term process, not as one event, and as a series of stages or phases (Fiegener, Brown, Prince \& File 1994; Sharma, 2004).

The bulk of researches carried out on succession and the study of successors over the years tends to favour male successors over female successors by parents. This is even given credence to by extant culture especially in Africa where inheritance is patriarchal in nature. Emphasizing this, Nnabuife, Okoli \& Arachie (2018) avers that emphasis has always been placed on the male child especially in the family system mainly because families in Nigeria are patrilineal. Similarly, Nwadukwe (2012), states that whenever a man dies, his property including his business ventures are divided among the deceased male children only. This has limited the chances of female succeeding their parents in business. Furthermore, it is usually the case that potential male successors are seen as preferable and more suited to the top management positions within a family company in the future (Fritsch, 2017).

The culture that favours male children in the succession processes has succeeded in relegating female children in line of succession to the background. Corroborating this, Fritsch (2017) opines that indeed, daughters of family business owners are still in their brothers' shadows when it comes to becoming successors. The culture of Anambra State makes it explicit that it is the male child or children that inherit the properties of the deceased and this appears to segregate against the female child (Nnabuife, Okoli \& Arachie, 2018). Traditionally, there are particular and extraordinary challenges for daughters aspiring to the 
top leadership position in their own family's enterprise (Allen \& Langowitz, 2003). This challenges and obstacles have skewed succession towards male children and has limited the potential of business minded female child to take up the mantle of leadership in their family businesses.

\subsection{Sexism and Succession in Family Owned Businesses}

Sexism ordinarily means ascribing more quality and capacity to one sex or gender over the other. There is this general belief that one sex is inherently more superior than the other. A discriminatory or different treatment of people that is based entirely on their sex is known as sexism. Within the context of this study, the gender being referred to as being discriminated against is women or the female gender. It refers to discriminatory practices against women, including overt and nuanced or subtle forms of sexism (Benokraitis \& Feagin, 1986; Benokraitis, 1997).

Sexism could be overt or covert. Overt sexism being very obvious and easily documented and fought against while the covert type is difficult to detect and fight against. The overt form of sexism is increasingly becoming radically unacceptable as against covert ones which are still very much in practice today. Overbeke, Bilimoria \& Somers (2015) opine that overt sexism, or acts such as sexual harassment that can be documented or easily distinguished, have become less socially acceptable. Covert sexism also known as subtle sexism could be categorized into various forms. Benokraitis (1997) theorized that there are nine forms of subtle sexism including condescending chivalry, supportive discouragement, friendly harassment, subjective identification and radiant devaluation. Others are liberated sexism, benevolent exploitation, considerate domination, and collegial exclusion. These subtle forms of sexism are at paradoxical or oxymoron's where contradictory words are used to conceal the real meaning. The names of these categories are oxymoron's meant to highlight the mixed messages they send and to emphasize the seemingly supportive behaviour that has pernicious consequences (Benokraitis, 1997).

Some of the meanings of subtle sexism are given thus: liberated sexism refers to a process where equality is presumed, but in practice, men's freedom increases while women's workload increases. Collegial exclusion refers to a form of subtle sexism where women are made to feel invisible or unimportant through physical, social, or professional isolation (Overbeke, Bilimoria \& Somers, 2015). These acts of subtle sexism have some cultural and traditional coloration. That is, it is supported by the culture of a people especially in Africa. They are embedded in cultural and societal norms and permeate multiple levels of society, including individual, organizational, institutional, and cultural (Overbeke, Bilimoria \& Somers, 2015). Constantinidis \& Nelson (2009) posit that the role of daughters in family enterprise is heavily influenced by the societal context that relates and distinguishes the role and expectations of women in business, and in the family.

There is a sex-based preference that favours sons over daughters as managerial business heirs (Allen \& Langowitz, 2003; Miller, Steier \& Breton-Miller, 2003), regardless of experience or temperament to lead. Daughters usually do not expect to become successors (Jimenez, 2009) and do not share in the grooming process. Collegial exclusion thus begins at an early age in 
family businesses (Overbeke, Bilimoria \& Somers, 2015). Similarly, parents may use verbal persuasion to instil a sense of competency in their daughters. Daughters may be told they may aspire to anything, yet a structure of opportunities leading to succession typically excludes them (Iannarelli, 1992; Curimbaba, 2002).

\subsection{Obstacles to Women Succession in Family Owned Businesses}

A lot of factors over the years have been ascribed as obstacles in the way of women becoming successful successors especially in the family business context. These factors range from cultural impediments to societal belief system and glass ceiling. Martinez-Jimenez (2009) posits that the main factors in family business that prevent women's involvement in top leadership positions have been classified into three main categories: glass ceiling and women's invisibility, emotional leadership, succession and primogeniture.

Glass ceiling is an invisible barrier or obstacle; it is subtle and transparent but strong and it prevents women from moving up in higher professional position (Morrison, White, \& Van Velsor, 1987 cited in Faraudello \& Songini, 2018). It "is not simply a barrier for an individual, based on the person's inability to handle a higher-level job, rather, it applies to women as a group who are kept from advancing higher because they are women" (Morrison et al., 1987). Women's invisibility is also another barrier to being successors in FOBs. Women's invisibility in FOB is related to relegating the role of women to that of family care giver. This is their primary role while other roles they play in the business are relatively supportive in nature. Rowe and Hong (2000) writes that commonly, women's main tasks are related to managing the house and the family, while the other responsibilities connected to the business are considered secondary and these cultural traditions are the basis for the woman's invisibility in family firms. Corroborating this, Faraudello \& Songini (2018) opine that especially in the past, women's professional capabilities and competencies were mostly ignored, in both family and non-family businesses. Many wives and daughters and women in general, play several roles in firms but generally they are felt like being invisible, with no consideration and no monetary gain.

Also contributing as obstacles to women being successors in FOBs is "Same Gender Succession". Women rarely start off FOBs as majority of the business are founded by fathers and they would love to hand over to their sons, thus dampening the chances of women or female children succeeding them in the business. Martin (2001) posits that another factor which causes tension and reduces the chances of women succeeding in FOBs is that, when the owner of the family business is a father, which is often the case, he may want to protect 'daddy's little girl' from a rough working environment and unpleasant experiences; in essence, daughters can be kept in this diminished role by their fathers. Some authors affirm that father-daughter succession is less competitive and conflicting than father-son succession (Haberman \& Danes, 2007).

There is also the issue of competence and capability of women to be good business managers and these have over the years inhibited women from being successors in FOBs. Küste (2003) states that the prejudices surrounding female successors and reservations about their potential success come from the family and especially the father's perspective include the following: 
untypical industry for women increased family predisposition, lower physical resilience, lack of acceptance by the business partners, greater need for security, and less marked leadership affinity.

Some of the inhibiting factors militating against women being successors to family business are given below:

i. Cultural issues

ii. Perceived lack of business competences

iii. The traditional role of women

iv. Same gender succession

v. Sexism

vi. Patriarchal mentality

vii. Lack of business interest from the female gender

\section{Empirical Review}

Nnabuife, Okoli and Arachie (2018) examined the relationship between Cultural Dynamics and Performance of selected Family Owned Businesses in Anambra State. The study adopted a survey research design with a population of 1500 FOB's and a sample size of 316 . Data were collected through questionnaire and analysed with the aid of descriptive statistics and hypothesis tested with the Ordinary least square Regression analysis at 5\% level of significance. The result indicated that there was a positive relationship existing between inheritance culture and professionalism in the selected FOBs. It was therefore concluded that the culture of an environment overlaps with the culture of FOBs situated in it. Among other things, it was recommended that irrespective of the fact that the ownership of the business stays within the family circle, efforts should be made by the families to employ capable hands and experts to help in managing the business.

Utami and Sintha (2017) analysed whether the management succession patterns including a personality system, a family system, an ownership right system and a management system become the primary factors determining the success of the family business. The results of the study, using Partial Least Square showed that Family System variable had significant influence on Sustainability of Family Business. Meanwhile, Personality System, Ownership System and Personality system variables had no significant effects on Sustainability of the family business.

Sentuti (2017) did a study which focused on the intergenerational transfer from female entrepreneurs to offspring, analysing two Italian cases of succession from mother to son or daughter. The aim was to find out how succession unfolds when the incumbent is a woman, and whether specific characteristics of women's style of leadership and management may facilitate the planning and management of the intergenerational transfer. Findings from the study revealed that the female approach to the succession process is characterised by 
attention to relationships, cooperation, involvement, communication and sharing in the decision-making process. Moreover, the female approach appears to be more orientated towards a positive perspective of succession. Women entrepreneurs seem to live through the intergenerational transfer much less traumatically, adopting an idea of the physiological continuity of the business and natural turnover between the generations.

Mair and Bitsch (2017) assessed the perspectives of those involved in the succession process through a qualitative research approach. Based on in-depth interviews, a comparative analysis led to the development of a substantial grounded theory of succession in horticultural family businesses. Results from the study showed a range of determining factors, including socialization of the potential successor, affecting the generation spanning succession process.

Fritsch (2017) carried out a study to identify potential challenges a female successor faces when taking over a family business and whether various strategic and/or structural requirements need to be considered by the daughter within the succession process. Empirical data for the study was gathered within the methodological framework of the grounded theory. Semi-guided expert interviews were conducted to gain empirical insights. The results indicated that the challenges each individual successor experienced as most crucial or difficult will always depend on her personal character, on the senior family members' behaviour during the succession process, and on the company's hand-over capability at the outset of the process. It was therefore concluded that succession process is very complex and burdened with emotions from the family members. However, having a clear road map for succession that leaves room for improvement in case of unpredictable factors in advance can be essential for the success of the succession.

\section{Methodology and Analysis}

This work adopted a survey research design because data were collected from individuals about variables of the study and this makes survey the best design. Anambra State Nigeria is the area where the study was carried out. The population of the study was 415 FOBs in Anambra State carefully selected to reflect the 21 Local Government Areas in the State. Out of this number, 315 were unincorporated while 100 were incorporated and the source was from Anambra State Ministry of Commerce (2018). Because of the sensitive nature of the study, complete enumeration method is adopted so as to get the opinion of all the firms on gender issues and female succession. The data for the study was gotten through structured questionnaire and interview. The questionnaire was however validated using content validity method while the reliability was derived using Cronbach Alpha method and the coefficient obtained was .817. At the end, 368 copies of questionnaire were analysed because 47 copies were either not returned or wrongly filled or incompletely checked. This shows that questionnaire analysis proportion against the population of the study was $89 \%$. A combination of descriptive simple percentages, mean and standard deviations were deployed in the data analysis while inferential statistics, Chi-square was used in testing the hypotheses. The study made use of 5\% (.05) significant level which helped in making decision after the analysis. 
4.1 Data Analysis

\subsubsection{Descriptive Statistics}

Table 1. Questionnaire on obstacles facing women in being successors of FOBs

\begin{tabular}{|c|c|c|c|c|c|c|c|c|c|}
\hline $\mathbf{S} / \mathbf{N}$ & Questionnaire Items & $\begin{array}{l}\text { SA } \\
\text { (5) }\end{array}$ & $\begin{array}{l}\text { A } \\
\text { (4) }\end{array}$ & $\begin{array}{l}\text { UD } \\
\text { (3) }\end{array}$ & $\begin{array}{l}D \\
\text { (2) }\end{array}$ & $\begin{array}{l}\text { SD } \\
\text { (1) }\end{array}$ & $\mathbf{X}$ & Dec. & Pos. \\
\hline & $\begin{array}{l}\text { Obstacles Preventing Women } \\
\text { from being Successors in FOBs }\end{array}$ & & & & & & & & \\
\hline 1 & $\begin{array}{l}\text { Our culture favours male children } \\
\text { from inheriting business over } \\
\text { female. }\end{array}$ & 219 & 121 & 5 & 23 & - & 4.46 & Accept & $1^{\mathrm{st}}$ \\
\hline 2 & $\begin{array}{l}\text { It is believed that male children } \\
\text { will do better at managing } \\
\text { business than female. }\end{array}$ & 198 & 55 & - & 77 & 38 & 3.81 & Accept & $3^{\text {rd }}$ \\
\hline 3 & $\begin{array}{l}\text { Female are seen to be better } \\
\text { managers at home than in } \\
\text { business. }\end{array}$ & 225 & 102 & 12 & 29 & - & 4.42 & Accept & $2^{\text {nd }}$ \\
\hline 4 & $\begin{array}{l}\text { The owners of family businesses } \\
\text { prefer to hand over their } \\
\text { businesses to their male children. }\end{array}$ & 112 & 150 & 47 & 38 & 21 & 3.80 & Accept & $4^{\text {th }}$ \\
\hline 5 & $\begin{array}{l}\text { Because of the closeness of male } \\
\text { children to their parent's business } \\
\text { from early stage, they tend to be } \\
\text { preferred to women in business. }\end{array}$ & 171 & 90 & 11 & 46 & 50 & 3.78 & Accept & $5^{\text {th }}$ \\
\hline 6 & $\begin{array}{l}\text { Females are perceived to have } \\
\text { better business knowledge than } \\
\text { males. }\end{array}$ & 102 & 129 & 21 & 80 & 36 & 3.49 & Accept & $6^{\text {th }}$ \\
\hline 7 & $\begin{array}{l}\text { The emotions of women make } \\
\text { them appear weak in management } \\
\text { of business. }\end{array}$ & 98 & 138 & 17 & 45 & 70 & 3.40 & Accept & $7^{\text {th }}$ \\
\hline 8 & $\begin{array}{l}\text { The business society is dominated } \\
\text { by men and therefore women are } \\
\text { seen as not being able to compete } \\
\text { favourably with men. }\end{array}$ & 40 & 198 & 8 & 90 & 32 & 3.34 & Accept & $8^{\text {th }}$ \\
\hline
\end{tabular}

Source: Field Survey, 2019.

Table 1 show the questionnaire used in measuring the obstacles militating against women from being successors. From the table judging from the mean which benchmark of acceptance is 3 ; it is revealed that all the questionnaire items were accepted as being challenges facing women from being successors. But judging by degree using the mean value, 


\section{Macrothink}

it shows that culture is the greatest challenge (questionnaire item 1) followed by perception of women being better home managers than business managers (questionnaire item 3). The lowest factor judging from the least mean value was women being able to compete as a result of men dominated business world (questionnaire item 8). This is followed by the emotions of women making them weak in managing business (questionnaire item 7).

Table 2. Questionnaire on Sexism

\begin{tabular}{|c|c|c|c|c|c|c|c|c|c|}
\hline $\mathbf{S} / \mathbf{N}$ & Questionnaire Items & $\begin{array}{l}\text { SA } \\
\text { (5) }\end{array}$ & $\begin{array}{l}\text { A } \\
\text { (4) }\end{array}$ & $\begin{array}{l}\text { UD } \\
\text { (3) }\end{array}$ & $\begin{array}{l}\text { D } \\
\text { (2) }\end{array}$ & $\begin{array}{l}\text { SD } \\
\text { (1) }\end{array}$ & $\mathbf{X}$ & Dec. & Pos. \\
\hline & Sexism & & & & & & & & \\
\hline 1 & $\begin{array}{l}\text { I do not care whether it is my } \\
\text { male or a female child that will } \\
\text { inherit my business. }\end{array}$ & 45 & 99 & 18 & 108 & 98 & 2.69 & Reject & $8^{\text {th }}$ \\
\hline 2 & $\begin{array}{l}\text { I will prefer to have my son to be } \\
\text { in charge of my business when I } \\
\text { am gone. }\end{array}$ & 121 & 70 & - & 82 & 95 & 3.11 & Accept & $6^{\text {th }}$ \\
\hline 3 & $\begin{array}{l}\text { I see female children as weak } \\
\text { when it comes to handling } \\
\text { business. }\end{array}$ & 79 & 150 & 6 & 82 & 51 & 3.34 & Accept & $5^{\text {th }}$ \\
\hline 4 & $\begin{array}{l}\text { I prefer to have my female } \\
\text { children at home to take care of } \\
\text { the house than in the business } \\
\text { place. }\end{array}$ & 158 & 121 & - & 52 & 37 & 3.85 & Accept & $1^{\text {st }}$ \\
\hline 5 & $\begin{array}{l}\text { Women are better at being } \\
\text { supporters in business than being } \\
\text { in charge. }\end{array}$ & 100 & 103 & 9 & 156 & - & 3.40 & Accept & $4^{\text {th }}$ \\
\hline 6 & $\begin{array}{l}\text { If I am faced with the option of } \\
\text { choosing a male or a female } \\
\text { successor, I will choose a male } \\
\text { successor. }\end{array}$ & 134 & 131 & 3 & 33 & 67 & 3.63 & Accept & $3^{\text {rd }}$ \\
\hline 7 & $\begin{array}{l}\text { I believe those females are not } \\
\text { weaker than male in handling } \\
\text { business issues. }\end{array}$ & 111 & 59 & 8 & 102 & 88 & 3.01 & Accept & $7^{\text {th }}$ \\
\hline 8 & $\begin{array}{l}\text { I would not resist my female } \\
\text { child from handling my business } \\
\text { if she has the capacity to do so. }\end{array}$ & 98 & 173 & - & 73 & 24 & 3.67 & Accept & $2^{\text {nd }}$ \\
\hline
\end{tabular}

Source: Field Survey, 2019.

Table 2 shows questionnaire used in measuring sexism as it relates to making choice of successor in the FOBs studied. Judging from the mean, it is seen that the highest act of 


\section{Macrothink}

sexism encountered by women was preference to having then at home rather than in the business place (questionnaire item 4). Ironically, the respondents posited that they would not resist their female children to handle their business if they have the capacity as this question produced the second highest mean. The lowest mean from the questionnaire items was questionnaire one which produced a mean below the benchmark of 3 . This questionnaire shows that the respondents cares about who takes over the business along gender line. They however believe that women are not weaker than male in handling business as shown by a mean of 3.01; this is however slightly above the threshold.

\subsection{Test of Hypotheses}

\subsubsection{Hypothesis One}

There are no obstacles to women succeeding their parents in FOB's in Anambra State.

Table 3. Chi-square Output for Obstacles facing women to be successors

\begin{tabular}{llll}
\hline Chi-Square Tests & & & \\
\hline & Value & df & $\begin{array}{l}\text { Asymp. } \\
\text { (2-sided) }\end{array}$ \\
\hline Pearson Chi-Square & $882.425^{\text {a }}$ & 28 & .000 \\
Likelihood Ratio & 897.908 & 28 & .000 \\
Linear-by-Linear & 224.811 & 1 & .000 \\
Association & 3044 & & \\
N of Valid Cases & & & \\
\hline
\end{tabular}

Note. a. 0 cells $(0.0 \%)$ have expected count less than 5 . The minimum expected count is 26.72 .

Source: SPSS output from Field Survey, 2019.

Table 3 shows the chi-square output for the obstacles militating against women to being successors of FOBs in Anambra State. The result showed that these obstacles as captured in table 1 have significant effect on women being successors of FOBs in Anambra state. This is judging from the Pearson Chi-Square Coefficient which is 882.425 and the asymptomatic significance which 0.000 (asymptomatic significance $<$ significance level 0.05 ). The null hypothesis is therefore rejected in favour of the alternate hypothesis. 


\section{Macrothink}

Table 4. Test of size effect as Obstacles

\begin{tabular}{llll}
\hline \multicolumn{4}{l}{ Symmetric Measures } \\
\hline Nominal & byPhi & Value & Approx. Sig. \\
Nominal & Cramer's V & .269 & .000 \\
N of Valid Cases & & 3044 & \\
\hline
\end{tabular}

Note. a. Not assuming the null hypothesis. b. Using the asymptotic standard error assuming the null hypothesis.

Source: SPSS output from Field Survey, 2019.

Table 4 reveals the effect size of the obstacles facing women from being successors of FOBs in Anambra state. From the Phi coefficient as indicated in Table 4, at .538 (50\%), it is revealed that cumulatively, the obstacles as captured in Table 1 have a moderately significant effect on women successors of FOBs in Anambra State.

\subsubsection{Hypothesis Two}

Sexism does not play a role in determining a successor to FOBs in Anambra State

Table 5. Chi-square Output for Sexism

\begin{tabular}{lllll}
\hline Chi-Square Tests & & & & \\
\hline & Value & df & $\begin{array}{l}\text { Asymp. } \\
\text { (2-sided) }\end{array}$ & Sig. \\
\hline Pearson Chi-Square & $489.625^{\text {a }}$ & 28 & .000 \\
Likelihood Ratio & 557.379 & 28 & .000 \\
Linear-by-Linear & 46.466 & 1 & .000 \\
Association & 2944 & & \\
N of Valid Cases & & & \\
\hline
\end{tabular}

Note. a. 0 cells $(0.0 \%)$ have expected count less than 5 . The minimum expected count is 5.50 .

Source: SPSS output from Field Survey, 2019.

Table 5reveals the chi-square result for sexism as it relates to FOBs in Anambra State. From the result, it showed that sexism plays a significant role in determining successors of FOBs in Anambra State. This is owing to the fact that the Pearson Chi-Square Coefficient obtained is 489.625 and the asymptomatic significance was 0.000 which is less than 0.05 level of significance used. Judging by this result, the null hypothesis is rejected in favour of the alternate hypothesis. 


\section{Macrothink}

Table 6. Test of effect size for Sexism

\begin{tabular}{lccc}
\hline \multicolumn{2}{l}{ Symmetric Measures } & Value & Approx. Sig. \\
\hline Nominal & byPhi & .408 & .000 \\
Nominal & Cramer's V & .204 & .000 \\
N of Valid Cases & & 2944 & \\
\hline
\end{tabular}

Note. a. Not assuming the null hypothesis; b. Using the asymptotic standard error assuming the null hypothesis.

Source: SPSS output from Field Survey, 2019.

Table 5 shows the effect size of the role sexism plays on determining successors of FOBs in Anambra state. The Phi coefficient obtained is .408 (40\%). This reveals that cumulatively, sexism plays a moderate role on determining successors of FOBs in Anambra State.

\section{Findings}

From the analysis of hypothesis one bothering on the obstacles women face in becoming successors of FOBs in Anambra State, the result shows that these obstacles as shown in table 1 have statistical significant effects on women becoming successors of FOBs in Anambra State with a chi-square coefficient of 882.425 (asymptomatic significance $<$ significance level $0.05)$ and an effect size of $0.538(50 \%)$ as captured by Phi coefficient.

From the analysis of the hypothesis two which deals with the role sexism play in determining successor, the result reveals that indeed sexism play a statically significant role in determining successors in Anambra State with a Pearson Chi-Square Coefficient of 489.625(asymptomatic significance $<$ significance level 0.05 ) and an effect size of 0.408 (40\%) as depicted by the Phi coefficient.

\section{Conclusion and Recommendations}

Sequel to the findings of the study, it is concluded that women and men in Anambra state do not have a level playing field in determining who becomes a successors of FOBs in Anambra state as there are huddles women face and these obstacles have significant effect on who becomes a successors. Also, sexism plays a role in determining successors of FOBs in Anambra state as depicted by the findings of the study.

The study recommends the following:

a) That succession choice of FOBs should not be based on gender and sexism but on the capacity to deliver effectively and efficiently.

b) That level playing field and opportunities should be provided for women to compete with their male siblings so as to give them confidence to deliver when given the reign of business ownership or management. 
c) As parent start taking male children to the business arena at early stage, female children should also be taken to give the opportunity to develop business consciousness at early stage.

\section{References}

Adedayo, S. O., \& Ojo, J. O. (2016). Family Conflict and Sustainability of Family Owned Businesses in Lagos and Ogun States, Nigeria. Pyrex Journal of Business and Finance Management Research, 2(8), 89-96.

Ahrens, J., Landmann, A., \&Woywode, M. (2015). Gender preferences in the CEO successions of family firms: Family characteristics and human capital of the successor. Journal of Family Owned Business Strategy, 6, 86-103.

Allen, I. E., \& Langowitz, N. S. (2003). Women in family-owned businesses. MassMutual and Centre for Women's Leadership, Babson College.

Astrachan, J. H., \& Shanker, M. C. (2003). Family businesses' contribution to the U.S. economy: a closer look. Family Business Review 26, 211-219. https://doi.org/10.1111/j.1741-6248.2003.tb00015.x

Küstel, A. (2003). Situations analysezu Personal- und Nachfolgebe- darfen von Unternehmen in Mecklenburg-Vorpommern imHinblick auf neueberuflicheChancenfür Frauen in Führungspositionen, ATI Küste $\mathrm{GmbH}$, Gesell- schaftfürTechnologie und Innovation. Germany.

Benokraitis, N. V. (1997). Subtle Sexism. Thousand Oaks, CA: Sage Publications.

Benokraitis, N. V., \& Feagin, J. R. (1986). Modern Sexism: Blatant, Subtle, and Covert Discrimination. Englewood Cliffs, NJ: Prentice-Hall.

Constantinidis, C., \& Nelson, T. (2009). Integrating Succession and Gender Issues from the Perspective of the Daughter of Family Enterprise across the U.S. and EU », International Management, 14(1), 43-54.

Cullen, M. D. M. (2007). The development of a model to promote sustainable strategic entrepreneurial behaviour of family estate wine businesses in the South African Wine Industry. (Published PhD. Thesis). Port Elizabeth. Nelson Mandela Metropolitan University

Curimbaba, F. (2002). The dynamics of women's roles as family business managers. Family Business Review 15, 239-252. https://doi.org/10.1111/j.1741-6248.2002.00239.x

Economic Intelligence Unit (2013). Family and Enterprise Chapter. In Carter, S. and Evans-jones, D. (Eds.), Enterprise and Small Business: Principles, Practice and Policy.

Efferin, S., \& Hartono, M. S. (2015). Management control and leadership styles in family business: An Indonesian case study. Journal of Accounting \& Organizational Change, 11(1), 130-159.

Faraudello \& Songini (2018). Women's Role in Family Business: Evolution and Evidences from a European Case Study. Journal of Modern Accounting and Auditing, 14(2), 70-89. 
https://doi.org/10.17265/1548-6583/2018.02.003

Fiegener, M. K., Brown, B. M., Prince R. A., \& File, K. M. (1994). A comparison of successor development in family and nonfamily businesses. Family Business Review, 7(4), 313-329.

Fritsch, T. (2017). Challenges of a Female Successor of a Family Business. Master Thesis submitted at the IMC FachhochschuleKrems (University of Applied Sciences).

Haberman, H., \& Danes, S. M. (2007). Father-daughter and father-son family business management transfer comparison: family FIRO model application. Family Business Review, 20(2), 163-184.

Henry, M., Erwee, R., \& Kong, E. (2013). Family Business Succession - Trust and Gender Issues in Family and Non-Family Succession. European Academy of Management (EURAM) Conference, $26^{\text {th }}-29^{\text {th }}$.

Iannarelli, C. L. (1992). The Socialization of Leaders in Family Business: An Exploratory Study of Gender. Pittsburgh, PA: University of Pittsburgh.

Jimenez, R. M. (2009). Research on women in family firms: current status and future directions. Family Business Review, 22(1), 53-64.

Maas, G., \& Diederichs, A. (2007). Manage family in your business. Northcliff: Frontrunner Publishing.

Mair \& Bitsch (2017).Succession in Horticultural Family Businesses: Determining Factors. International Journal of Food System Dynamics, 313-322. https://doi.org/http://dx.doi.org/10.18461/pfsd.2017.1733

Martí, J, Menéndez-Requejo, S., \& Rottke, O. M. (2013). The impact of venture capital on family businesses: Evidence from Spain. Journal of World Business, 48(3), 420-430.

Martin, L. (2001). More jobs for the boys: Succession planning in SMEs. Women in Management Review, 6(5/6), 222-231.

Martinez, J. R. (2009). Research on women in family firms: Current status and future directions. Family Business Review, 22(1), 53-64.

Miller, D., Steier, L., \& Breton-Miller, I. (2003). Lost in time: Intergenerational succession, change, and failure in family business », Journal of Business Venturing, 18(4), 513-531.

Morrison, A., White, R., \& Van Velsor, E. (1987). Breaking the glass ceiling: Can women reach the top of America's largest corporations? Reading, MA: Addison-Wesley.

Nnabuife, E. K., \& Okoli, I. E. (2017). Succession Planning and Sustainability of Selected Family Owned Businesses in Anambra State, Nigeria. European Journal of Business and Management, 9(34), 155-167.

Nnabuife, K. N. E., Okoli, I. E., \& Arachie, A. E. (2018). Cultural Dynamics and Performance of Family Owned Businesses in Anambra State. Asian Journal of Economics, 
Business and Accounting, 8(4), 1-12.

Nwadukwe, U. C. (2012). The effect of Igbo inheritance culture on management succession in private Indigenous Enterprises in South Eastern Nigeria. (PhD Dissertation). Department of Management, Faculty of Business Administration, University of Nigeria, Enugu Campus.

Ogundele O.J.K., Idris A. A., \& Ahmed-Ogundipe K. A. (2012). Entrepreneurial succession problems In Nigeria's family businesses: A threat to sustainability, European Scientific Journal, 8(7).

Overbeke, K. K., Bilimoria, D., \& Somers, T. (2015). Shared vision between fathers and daughters in family businesses: the determining factor that transforms daughters into successors. Frontier Psychology, 6(25), 1-15. https://doi.org/10.3389/fpsyg.2015.00625

Oyeyinka, B.O. (2010). SME: Issues, Challenges and prospects, Financial System Strategy (FSS). 2020 International Conference.

Poutziouris, P. (2000). Venture capital and small and medium-sized family companies: An analysis from the demand perspective. In P. Poutziouris (Ed.), Family-Business Tradition or Entrepreneurship in the New Economy (pp. 255-282). Procceedings: Annual Family Business Network World Conference, FBN, London.

Poza, E. J. (2004). Family business. Mason, OH: South Western Thomas Publishers.

PriceWaterHouseCoopers, Family Business Survey 2007-2008. Retrieved from http://www.pwc.com/extweb/home.nsf/docid/1FB68AE4ADAFB42E85257395004EEC89

Rowe, B., \& Hong, G. (2000). The role of wives in family businesses: The paid and unpaid work of women. Family Business Review, 13(1), 1-13.

Schramy, S. (2010). Finanzierung von Familienunternhemen. Wiesbaden, Germany: Gabler.

Sentuti (2017). Female Entrepreneurs and Intergenerational Transfer: New Insights into the Succession Process. International Journal of Economic Behaviour, 7, 117-130.

Sharma, P. (2004). An overview of the field of family business studies: current status and directions for the future. Family Business Review, 17(1), 1-36.

Sharma, P., Chrisman, J.J., Pablo, A.L. \& Chua J. H. (2001). Determinants of initial satisfaction with the succession process in family firms: A conceptual model. Entrepreneurship Theory and Practice, 25(3), 17-35.

Sonfield, M., \& Lussier, R. N. (2009). Gender in family business ownership and management: a six-country analysis. International Journal of Gender and Entrepreneurship, 1(2), 96-117.

Sonfield, M. C., \& Lussier, R. N. (2004). First, Second, and Third Generation Family Firms: A Comparison. Family Business Review, 17(3), 189-202.

Utami, C. W., \& Sintha, D. B. (2017). The Pattern Analysis of Family Business Succession: A Study on Medium Scale Family Business in Indonesia. European Research Studies Journal, 2, 461-474. 


\section{Macrothink}

Journal of Entrepreneurship and Business Innovation

ISSN 2332-8851 2019, Vol. 6, No. 1

World Commission on Enviroment \& Development (1987). Our Common Future the Brund land Report. Oxford University Press: Oxford, UK.

\section{Copyright Disclaimer}

Copyright for this article is retained by the author (s), with first publication rights granted to the journal.

This is an open-access article distributed under the terms and conditions of the Creative Commons Attribution license (http://creativecommons.org/licenses/by/3.0/). 